Original Article

\title{
DEVELOPMENT AND VALIDATION OF STABILITY INDICATING CHROMATOGRAPHIC METHOD FOR SIMULTANEOUS ESTIMATION OF SACUBITRIL AND VALSARTAN IN PHARMACEUTICAL DOSAGE FORM
}

\author{
SHWETA MISHRA ${ }^{a^{*}}$, C. J. PATEL ${ }^{b}$, M. M. PATEL ${ }^{c}$
}

$\mathrm{a}^{*}$ Department of Pharmaceutical Analysis, Gujarat Technological University, Ahmedabad, Gujarat, India, bDepartment of Pharmaceutical Analysis, Shree Swaminarayan Sanskar Pharmacy College, Gandhinagar, Gujarat, India, cPrincipal, Shree Swaminarayan Sanskar Pharmacy College, Gandhinagar, Gujarat, India Email: shwetamishra821@yahoo.com

Received: 13 Apr 2017, Revised and Accepted: 22 Aug 2017

\section{ABSTRACT}

Objective: This study aims to develop and validate a stability indicating HPLC method for simultaneous estimation of sacubitril and valsartan in pharmaceutical dosage form.

Methods: Sacubitril and valsartan separation were achieved by LC-20 AT $\mathrm{C}_{18}$ (250 mm x $4.6 \mathrm{~mm}$ ) column and buffer (potassium phosphate, pH 3.0): methanol (50:50) as mobile phase, at a flow rate of $1 \mathrm{ml} / \mathrm{min}$ (millilitre per minute). Detection was carried out at $224 \mathrm{~nm}$ (nanometer). The different HPLC experimental parameters were optimized and the method was validated according to the standard guideline. Forced degradation experiments were carried out by exposing sacubitril and valsartan standard and sample for thermal, photolytic, oxidative and acid-base hydrolytic stress conditions.

Results: Retention time of sacubitril and valsartan were found to be 4.170 min (minute) and 6.530 min (minute) respectively. The method has been validated for linearity, accuracy, precision, LOD, and LOQ. Linearity observed for sacubitril is $12.25-36.75 \mu \mathrm{g} / \mathrm{ml}$ (microgram per milliliter) and for valsartan is $12.75-38.25 \mu \mathrm{g} / \mathrm{ml}$ (microgram per milliliter). The results showed that sacubitril and valsartan and the other degradation products were fully resolved and thus the proposed method is stability-indicating.

Conclusion: The proposed HPLC method was found to be simple, specific, precise, accurate, rapid and economical for simultaneous estimation of valsartan and sacubitril in bulk and tablet dosage form. Thus the validated economical method was applied for forced degradation study of sacubitril and valsartan tablet.

Keywords: Sacubitril, Valsartan, RP-HPLC, Stability indicating RP-HPLC method, Validation

(C) 2017 The Authors. Published by Innovare Academic Sciences Pvt Ltd. This is an open access article under the CC BY license (http://creativecommons.org/licenses/by/4.0/) DOI: http://dx.doi.org/10.22159/ijap.2017v9i5.19139

\section{INTRODUCTION}

Sacubitril is chemically 4-[[(2S, 4R)-5-ethoxy-4-methyl-5-oxo-1-(4phenyl-phenyl) pentan-2-yl] amino]-4-oxobutanoic acid [1]. Sacubitril is an antihypertensive drug used in combination with valsartan for the treatment of heart failure. [2-3]. Valsartan is a nonpeptide, orally active and specific angiotensin II receptor blocker acting on the AT1 receptor subtype. Valsartan is chemically $\mathrm{N}-(1$-oxopentyl)-N-[[2'(1Htetrazol-5-yl)[1,1'-biphenyl]-4-yl]methyl]-Lvaline [4-7]. Methods such as HPLC [8-10], LC-MS [11-12], protein precipitation [13] and

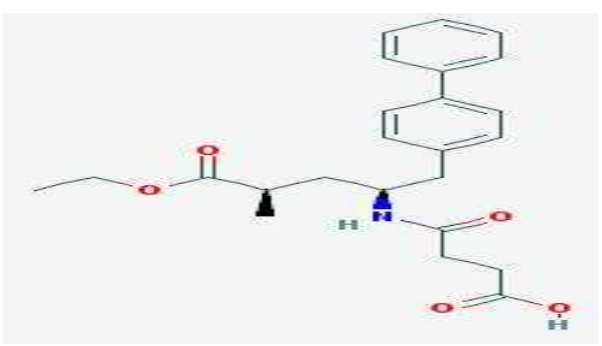

Fig. 1: Sacubitril structure from pub chem

\section{MATERIALS AND METHODS [17]}

\section{Materials and reagents}

Acetonitrile, potassium di-hydrogen phosphate, orthophosphoric acid and methanol of HPLC and AR grade were procured from Merck and Rankem lab ltd. Sacubitril and valsartan standards were received as gift samples from Yash Pharma and RPG Life Science, Ahmedabad, India, respectively. simultaneous UV-spectrophotometric methods [14-15] are reported for estimation of valsartan alone or in combination with other agents. A literature search reveals that only two analytical methods were reported for simultaneous estimation of sacubitril and valsartan from rat plasma using LC-MS/MS [16] and from a synthetic mixture using HPLC [17]. There is no stability indicating analytical methods were reported for simultaneous estimation of sacubitril and valsartan. Hence a simple, rapid, sensitive and accurate stability indicating HPLC method was developed for the simultaneous estimation of sacubitril and valsartan from API and pharmaceutical dosage form.

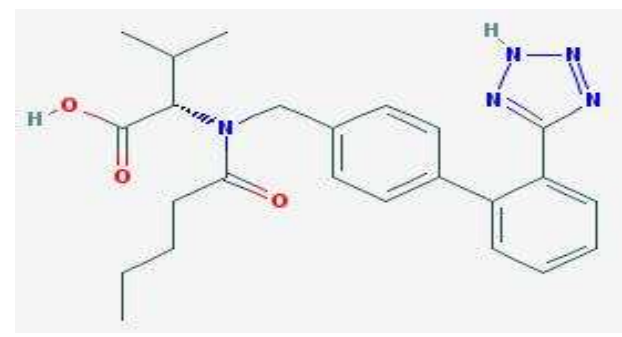

Fig. 2: Valsartan structure from pub chem

\section{Equipment}

Chromatographic separation was performed on HPLC system consist of model Shimadzu LC-20 AT having a SPD-20AT detector and rheodyne injector with $20 \mu \mathrm{l}$ loop volume. Spinchrom software was applied for data collecting and processing. UV spectrophotometer which consists of model Systronic 119 is also used to measure the wavelength of the solution of Sacubitril and Valsartan. 


\section{Preparation of standard stock solution}

Accurately weighed quantity of $24.5 \mathrm{mg}$ (milligram) sacubitril and $25.5 \mathrm{mg}$ (milligram) valsartan API were transferred into $100 \mathrm{ml}$ (milliliter) volumetric flask and dissolved in HPLC grade methanol using ultra sonication and diluted up to mark to give a stock solution having concentration of $245 \mu \mathrm{g} / \mathrm{ml}$ sacubitril and $255 \mu \mathrm{g} / \mathrm{ml}$ valsartan.

\section{Preparation of working standard solution}

From above standard stock solution of sacubitril and valsartan, $1 \mathrm{ml}$ of solution was taken into $10 \mathrm{ml}$ volumetric flask and was made to the mark with the mobile phase to get $24.5 \mu \mathrm{g} / \mathrm{ml}$ of sacubitril and $25.5 \mu \mathrm{g} / \mathrm{ml}$ of valsartan.

\section{Preparation of sample stock solution}

The average weight of 10 tablets was determined and was ground in a mortar. Sample stock solution was prepared by dissolving tablet powder equivalent to $24.5 \mathrm{mg}$ of sacubitril or $25.5 \mathrm{mg}$ of valsartan was transferred to $100 \mathrm{ml}$ volumetric flask. Then $60 \mathrm{ml}$ methanol was added and sonicated for $5 \mathrm{~min}$ to ensure complete solubilization of drug. After sonication, volume was made up to the mark with methanol. Filter the stock solution with whatman filter paper and the final filtrate is collected as sample stock solution.

\section{Chromatographic conditions}

A BDS hypersil $\mathrm{C}_{18}(250 * 4.6 \mathrm{~mm}, 5 \mu \mathrm{m})$ column was used as the stationary phase. A mixture of buffer ( $\mathrm{pH} 3.0)$ and methanol in the ratio of $(50: 50 \% \mathrm{v} / \mathrm{v})$ was used as a mobile phase and $\mathrm{pH} 3.0$ adjusted with ortho phosphoric acid. It was filtered through $0.45 \mu$ (micron) membrane filter and degassed. The mobile phase was pumped at $1.0 \mathrm{ml} / \mathrm{min}$. The eluents were monitored at $224 \mathrm{~nm}$. The injection volumes of sample and standard were $20 \mu \mathrm{l}$ (microliter). Total run time is $10 \mathrm{~min}$.

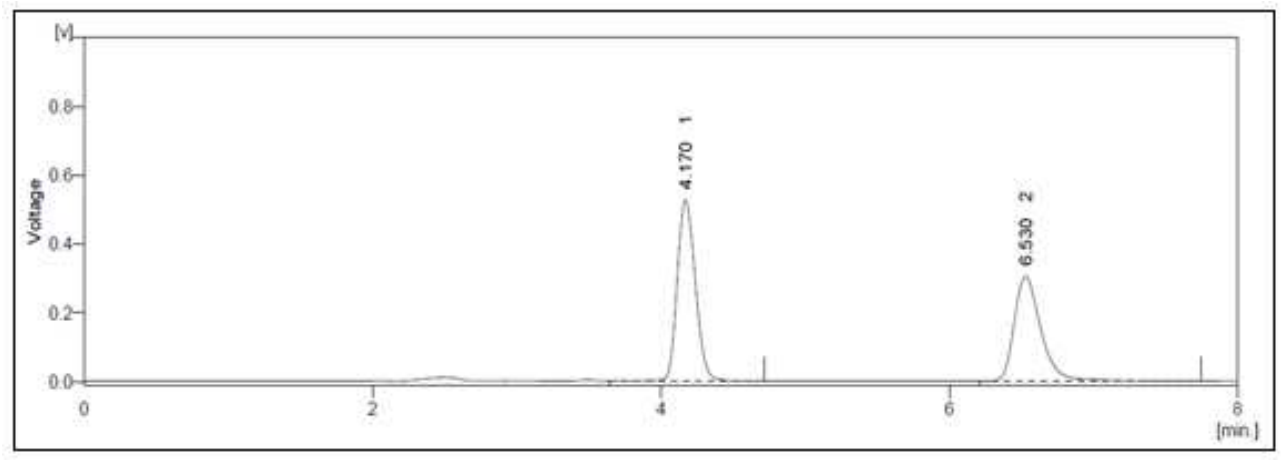

Fig. 3: Chromatogram of sacubitril and valsartan

The developed Method was validated for linearity, precision, accuracy, robustness and is applied for forced degradation studies as per the ICH guidelines [18-23]

\section{RESULTS AND DISCUSSION}

\section{Method validation}

The described method has been validated which include parameters like system suitability, linearity, accuracy, precision, robustness, LOD (limit of detection) and LOQ (limit of quantification).

\section{System suitability}

System suitability and chromatographic parameters were validated such as resolution, theoretical plates, and the tailing factor was calculated. The results are given in table 1.

Table 1: System suitability parameters for sacubitril and valsartan

\begin{tabular}{lll}
\hline System suitability parameter & Sacubitril & Valsartan \\
\hline Retention time (min) & 4.170 \\
Theoretical plate number (N) & 4915 & 6.530 \\
Tailing factor (T) & 1.313 \\
Resolution(R) & 8.332 \\
\hline
\end{tabular}

\section{Linearity}

The linearity of this method was evaluated by linear regression analysis and calculated by the least square method and studied by preparing standard solutions of sacubitril and valsartan at different concentration levels. The calibration curve showed (Fig. 4 and 5) good linearity in the range of $12.25-36.75 \mu \mathrm{g} / \mathrm{ml}$, for sacubitril with a correlation coefficient $\left(\mathrm{r}^{2}\right)$ of 0.999 and $12.75-38.25 \mu \mathrm{g} / \mathrm{ml}$ for valsartan with a correlation coefficient $\left(\mathrm{r}^{2}\right)$ of 0.999 . Results are given in table 2.

Table 2: Linearity data for sacubitril and valsartan

\begin{tabular}{lll}
\hline Drug & Conc $^{*}(\boldsymbol{\mu g} / \mathbf{m l})$ & Area \\
\hline Sacubitril & 12.25 & 2240.161 \\
& 18.375 & 3307.088 \\
& 24.5 & 4521.210 \\
& 30.625 & 5566.676 \\
Valsartan & 36.75 & 6772.742 \\
& 12.75 & 1878.693 \\
& 19.125 & 2773.397 \\
& 25.5 & 3791.580 \\
& 31.875 & 4668.280 \\
\hline
\end{tabular}

Conc*-concentration 


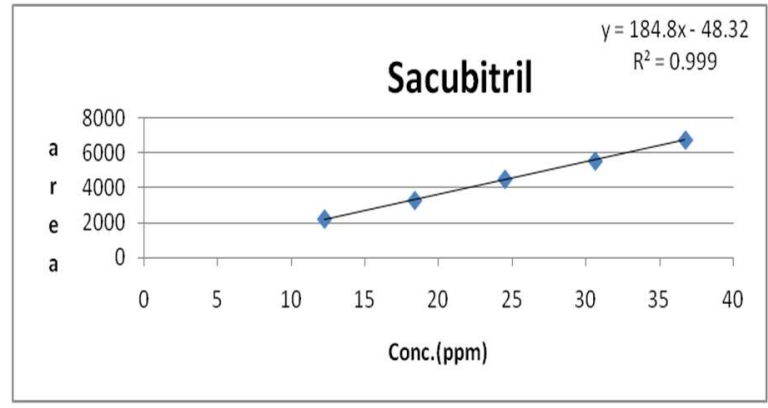

Fig. 4: Calibration curve of sacubitril

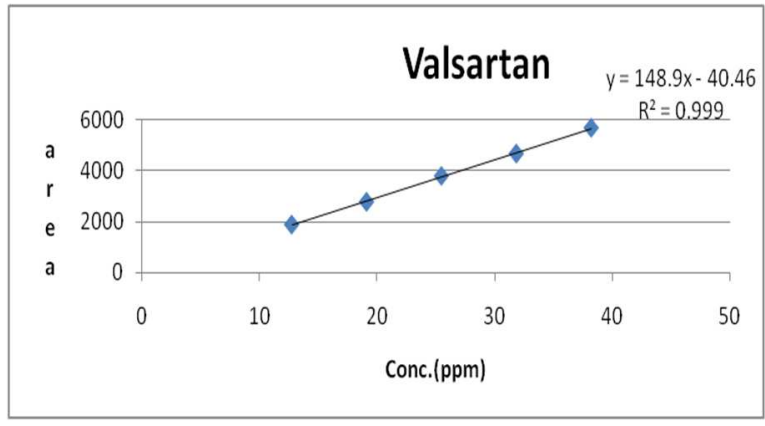

Fig. 5: Calibration curve of valsartan

\section{Accuracy}

Recovery studies were carried out by addition of the standard drug to the sample at 3 different concentration levels $(80 \%, 100 \%$ and $120 \%$ ) taking into consideration percentage purity of added bulk drug samples. At each concentration, the sample was injected thrice to check repeatability and from the \% RSD values it was analyzed that the method was accurate as \% recovery values found to be in the range of 99.72-100.02\% for the Sacubitril and 99.87-100.17\% for valsartan at three different concentrations $80 \%, 100 \%, 120 \%$.

The results are given in table 3 and 4 .

Table 3: Accuracy data for sacubitril

\begin{tabular}{|c|c|c|c|c|c|}
\hline $\begin{array}{l}\text { Conc* } \\
(\%)\end{array}$ & $\begin{array}{l}\text { Sample amount } \\
(\mu \mathrm{g} / \mathrm{ml})\end{array}$ & $\begin{array}{l}\text { Amount added } \\
(\mu \mathrm{g} / \mathrm{ml})\end{array}$ & $\begin{array}{l}\text { Amount recovered } \\
(\mu \mathrm{g} / \mathrm{ml})\end{array}$ & $\begin{array}{l}\% \\
\text { recovery }\end{array}$ & $\begin{array}{l}\text { \%mean } \\
\text { recovery } \pm \mathrm{SD}^{*}\end{array}$ \\
\hline \multirow[t]{3}{*}{$80 \%$} & 12.25 & 9.8 & 9.674 & 98.71 & $99.61 \pm 0.79$ \\
\hline & 12.25 & 9.8 & 9.796 & 99.96 & \\
\hline & 12.25 & 9.8 & 9.816 & 100.16 & \\
\hline \multirow[t]{3}{*}{$100 \%$} & 12.25 & 12.25 & 12.129 & 99.01 & $99.57 \pm 0.53$ \\
\hline & 12.25 & 12.25 & 12.259 & 100.07 & \\
\hline & 12.25 & 12.25 & 12.203 & 99.61 & \\
\hline \multirow[t]{3}{*}{$120 \%$} & 12.25 & 14.7 & 14.694 & 99.96 & $99.59 \pm 0.41$ \\
\hline & 12.25 & 14.7 & 14.574 & 99.14 & \\
\hline & 12.25 & 14.7 & 14.650 & 99.66 & \\
\hline
\end{tabular}

SD*-standard deviation, Conc*-concentration, Number of experiments (n)-3

Table 4: Accuracy data for valsartan

\begin{tabular}{lllll}
\hline Conc* (\%) $^{*} \begin{array}{l}\text { Sample amount } \\
(\boldsymbol{\mu g} / \mathbf{m l})\end{array}$ & $\begin{array}{l}\text { Amount added } \\
(\boldsymbol{\mu g} / \mathbf{m l})\end{array}$ & $\begin{array}{l}\text { Amount recovered } \\
(\boldsymbol{\mu g} / \mathbf{m l})\end{array}$ & \% recovery \\
\hline $80 \%$ & 12.75 & 10.2 & 10.067 & 98.70 \\
& 12.75 & 10.2 & 10.294 & 100.92 \\
& 12.75 & 10.2 & 10.215 & 100.15 \\
$100 \%$ & 12.75 & 12.75 & 12.622 & 99.00 \\
& 12.75 & 12.75 & 12.88 & 100.30 \\
$120 \%$ & 12.75 & 12.75 & 12.699 & 99.60 \\
& 12.75 & 15.3 & 15.317 & 100.11 \\
& 12.75 & 15.3 & 15.168 & 99.13 \\
\hline
\end{tabular}

$\mathrm{SD}^{*}$-standard deviation, Conc*-concentration, Number of experiments (n)-3 


\section{Precision}

\section{Repeatability}

A standard solution containing sacubitril $(24.5 \mu \mathrm{g} / \mathrm{ml})$ and valsartan $(25.5 \mu \mathrm{g} / \mathrm{ml})$ was injected six times and areas of peaks were measured and $\%$ RSD was calculated. The results are given in table 5.

\section{Intraday precision}

A standard solution containing $(12.25,24.5,36.75 \mu \mathrm{g} / \mathrm{ml})$ of sacubitril and $(12.75,25.5,38.25 \mu \mathrm{g} / \mathrm{ml})$ of valsartan were analyzed three times on the same day and \% R. SD was calculated. The results are given in table 6 .

\section{Interday precision}

A standard solution containing $(12.25,24.5,36.75 \mu \mathrm{g} / \mathrm{ml})$ of sacubitril $(12.75,25.5,38.25 \mu \mathrm{g} / \mathrm{ml})$ of valsartan were analyzed three times on a different day and \% RSD was calculated. The results are given in table 7 .

Table 5: Repeatability data for sacubitril and valsartan

\begin{tabular}{|c|c|c|c|c|}
\hline Drug & $\operatorname{Conc}^{*}(\mu \mathrm{g} / \mathrm{ml})$ & Area & Mean $\pm \operatorname{SD}^{*}(n=6)$ & \% RSD \\
\hline \multirow[t]{6}{*}{ Sacubitril } & 24.5 & 4503.25 & $4506.15 \pm 25.56$ & 0.57 \\
\hline & & 4457.79 & & \\
\hline & & 4521.20 & & \\
\hline & & 4530.26 & & \\
\hline & & 4507.76 & & \\
\hline & & 4516.61 & & \\
\hline \multirow[t]{6}{*}{ Valsartan } & 25.5 & 3776.45 & $3772.76 \pm 32.26$ & 0.86 \\
\hline & & 3784.03 & & \\
\hline & & 3708.86 & & \\
\hline & & 3799.17 & & \\
\hline & & 3780.24 & & \\
\hline & & 3787.81 & & \\
\hline
\end{tabular}

$\mathrm{SD}^{*}$-standard deviation, RSD*-relative standard deviation, Conc*-concentration, Number of experiments (n)-6

Table 6: Intraday data for sacubitril and valsartan

\begin{tabular}{llll}
\hline Drug & Conc* $(\boldsymbol{\mu g} / \mathbf{m l})$ & Area mean $\mathbf{m} \mathbf{S D}^{*}(\mathbf{n}=\mathbf{3})$ & \% RSD $^{*}$ \\
\hline Sacubitril & 12.25 & $2223.62 \pm 15.41$ & 0.63 \\
& 24.5 & $4475.65 \pm 51.86$ & 1.16 \\
Valsartan & 36.75 & $6728.43 \pm 32.64$ & 0.49 \\
& 12.75 & $1858.60 \pm 20.77$ & 1.12 \\
& 25.5 & $3745.33 \pm 51.48$ & 1.37 \\
\\
\hline
\end{tabular}

$\mathrm{SD}^{*}$-standard deviation, $\mathrm{RSD}^{*}$-relative standard deviation, Conc*-concentration, Number of experiments (n)-3

Table 7: Interday data of sacubitril and valsartan

\begin{tabular}{|c|c|c|c|}
\hline Drug & Conc $^{*}(\mu \mathrm{g} / \mathrm{ml})$ & Area mean $\pm \operatorname{SD}^{*}(n=3)$ & \% RSD \\
\hline \multirow[t]{3}{*}{ Sacubitril } & 12.25 & $2218.93 \pm 17.50$ & 0.79 \\
\hline & 24.5 & $4480.94 \pm 30.84$ & 0.69 \\
\hline & 36.75 & $6727.83 \pm 20.15$ & 0.30 \\
\hline \multirow[t]{3}{*}{ Valsartan } & 12.75 & $1850.82 \pm 28.78$ & 1.55 \\
\hline & 25.5 & $3732.18 \pm 63.54$ & 1.70 \\
\hline & 38.25 & $5619.57 \pm 45.30$ & 0.81 \\
\hline
\end{tabular}

$\mathrm{SD}^{*}$-standard deviation, $\mathrm{RSD}^{*}$-relative standard deviation, Conc*-concentration, Number of experiments (n)-3

\section{Robustness}

Small deliberate changes in chromatographic conditions such as a change in mobile phase ratio $(+2 \%)$, change in $\mathrm{pH}( \pm 2$ units $)$ and flow rate ( \pm 2 units) were studied to determine the robustness of the method. The results were in the factor of $(\% \mathrm{RSD}<2 \%)$ the developed RP-HPLC method for the analysis of sacubitril and valsartan. The results are given in table 8 and 9 .

Table 8: Robustness data for sacubitril

\begin{tabular}{llllll}
\hline Drug & $\begin{array}{l}\text { Area at flow rate } \\
\mathbf{( - 0 . 2 ~} \mathbf{~ m l} / \mathbf{m i n})\end{array}$ & $\begin{array}{l}\text { Area at flow } \\
\text { rate (+0.2 } \mathbf{~ m l} / \mathbf{m i n})\end{array}$ & $\begin{array}{l}\text { Area at } \\
\mathbf{p H} \mathbf{( - 0 . 2 )}\end{array}$ & $\begin{array}{l}\text { Area at } \mathbf{~ H} \\
\mathbf{( + 0 . 2 )}\end{array}$ & $\begin{array}{l}\text { Area at mobile } \\
\text { phase(-2) }\end{array}$ \\
\hline Sacubitril & 4628.12 & 4366.85 & 4577.39 & 4252.50 & 4580.41 \\
& 4688.80 & 4417.00 & 4643.53 & 4326.41 & 4629.58 \\
& 4706.76 & 4435.21 & 4661.51 & 4353.43 & 4656.83 \\
\% RSD $^{*}$ & 0.88 & 0.80 & 0.96 & 1.21 & 0.84 \\
\hline
\end{tabular}

RSD*-relative standard deviation, Number of experiments (n)-3 
Table 9: Robustness data for valsartan

\begin{tabular}{|c|c|c|c|c|c|c|}
\hline Drug & $\begin{array}{l}\text { Area at flow rate } \\
(-0.2 \mathrm{ml} / \mathrm{min})\end{array}$ & $\begin{array}{l}\text { Area at flow rate } \\
(+0.2 \mathrm{ml} / \mathrm{min})\end{array}$ & $\begin{array}{l}\text { Area at } \\
\text { pH }(-0.2)\end{array}$ & Area at $\mathrm{pH}(+0.2)$ & $\begin{array}{l}\text { Area at mobile } \\
\text { phase }(-2)\end{array}$ & $\begin{array}{l}\text { Area at mobile phase } \\
(+2)\end{array}$ \\
\hline \multirow[t]{3}{*}{ Valsartan } & 3917.08 & 3681.51 & 3879.05 & 3605.61 & 3875.17 & 3674.13 \\
\hline & 3827.40 & 3601.23 & 3894.17 & 3526.61 & 3777.54 & 3696.78 \\
\hline & 3947.18 & 3719.47 & 3909.24 & 3650.86 & 3909.63 & 3723.20 \\
\hline$\% \mathrm{RSD}^{*}$ & 1.60 & 1.65 & 0.39 & 1.75 & 1.78 & 0.66 \\
\hline
\end{tabular}

RSD*-relative standard deviation, Number of experiments (n)-3

\section{Limit of detection (LOD) and limit of quantification (LOQ)}

The LOD and LOQ were found to be $0.85 \mu \mathrm{g} / \mathrm{ml}$ and $2.580 \mu \mathrm{g} / \mathrm{ml}$ for sacubitril and $0.89 \mu \mathrm{g} / \mathrm{ml}$ and $2.687 \mu \mathrm{g} / \mathrm{ml}$ for valsartan estimated by using the standard formulas. The low values of LOD and LOQ illustrate that the developed method was sensitive, accurate and precise as it can detected and quantify with very low concentration. The result is given in table 10 .

Table 10: LOD and LOQ data for sacubitril and valsartan

\begin{tabular}{lll}
\hline Drug & LOD $^{*}$ & LOQ $^{*}$ \\
\hline Sacubitril & $0.85(\mu \mathrm{g} / \mathrm{ml})$ & $2.580(\mu \mathrm{g} / \mathrm{ml})$ \\
Valsartan & $0.89(\mu \mathrm{g} / \mathrm{ml})$ & $2.687(\mu \mathrm{g} / \mathrm{ml})$ \\
\hline
\end{tabular}

$\mathrm{LOD}^{*}$-limit of detection, $\mathrm{LOQ}^{*}$-limit of quantification

\section{Method development}

ICH prescribed stress conditions such as acidic, basic, oxidative, thermal and photolytic stresses were carried out.

\section{Acid degradation}

Acid decomposition studies were performed by refluxing $1 \mathrm{ml}$ of sample stock solution was transferred into $10 \mathrm{ml}$ of volumetric flask. $2 \mathrm{ml}$ of $0.1 \mathrm{~N} \mathrm{HCl}$ solutions were added and mixed well and put for 4 $\mathrm{h}$ at $70{ }^{\circ} \mathrm{C} 250 \mathrm{ml}$ round bottom flask. After a time period, the content was cooled to room temperature. Then the volume was adjusted with diluent to get $24.5 \mu \mathrm{g} / \mathrm{ml}$ for sacubitril and $25.5 \mu \mathrm{g} / \mathrm{ml}$ for valsartan. After making final solutions, it is injected into HPLC and the peak area and peak shapes were observed. Chromatogram of acid degradation on sample solution is shown below in fig. 6 .

\section{Base degradation}

Basic decomposition studies were performed by refluxing $1 \mathrm{ml}$ of sample stock solution was transferred into $10 \mathrm{ml}$ of volumetric flask. $2 \mathrm{ml}$ of $0.1 \mathrm{~N} \mathrm{NaOH}$ solutions were added and mixed well and put for $4 \mathrm{~h}$ at $70{ }^{\circ} \mathrm{C} 250 \mathrm{ml}$ round bottom flask. After a time period the content was cooled to room temperature. Then the volume was adjusted with diluent to get $24.5 \mu \mathrm{g} / \mathrm{ml}$ for sacubitril and $25.5 \mu \mathrm{g} / \mathrm{ml}$ for valsartan. After making final solutions, it is injected into HPLC and the peak area and peak shapes were observed. Chromatogram of base degradation on sample solution is shown below in fig. 7 .

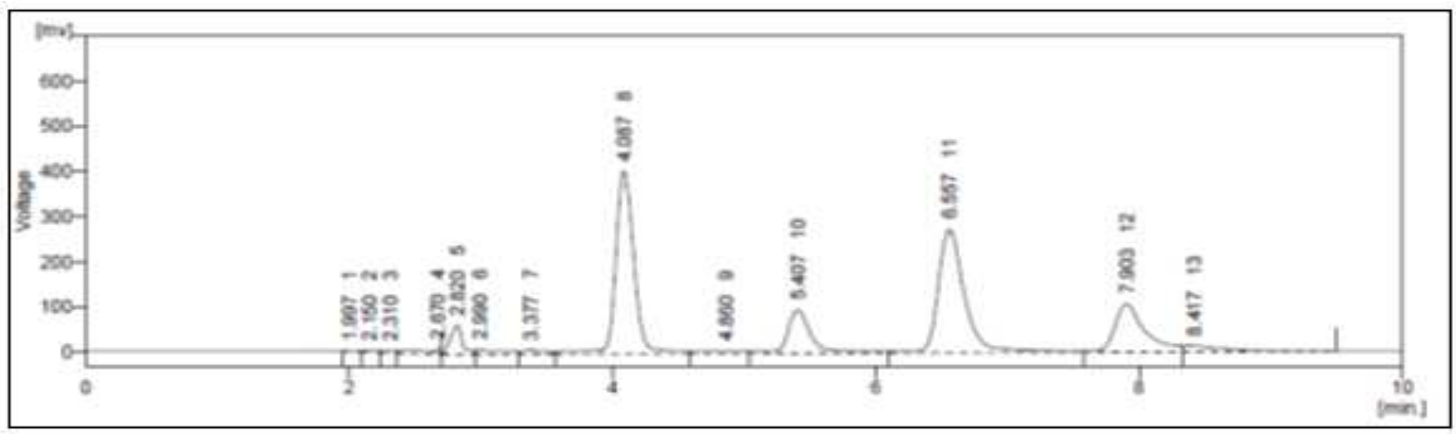

Fig. 6: Sacubitril and valsartan acid degradation sample at $4 \mathrm{~h}$

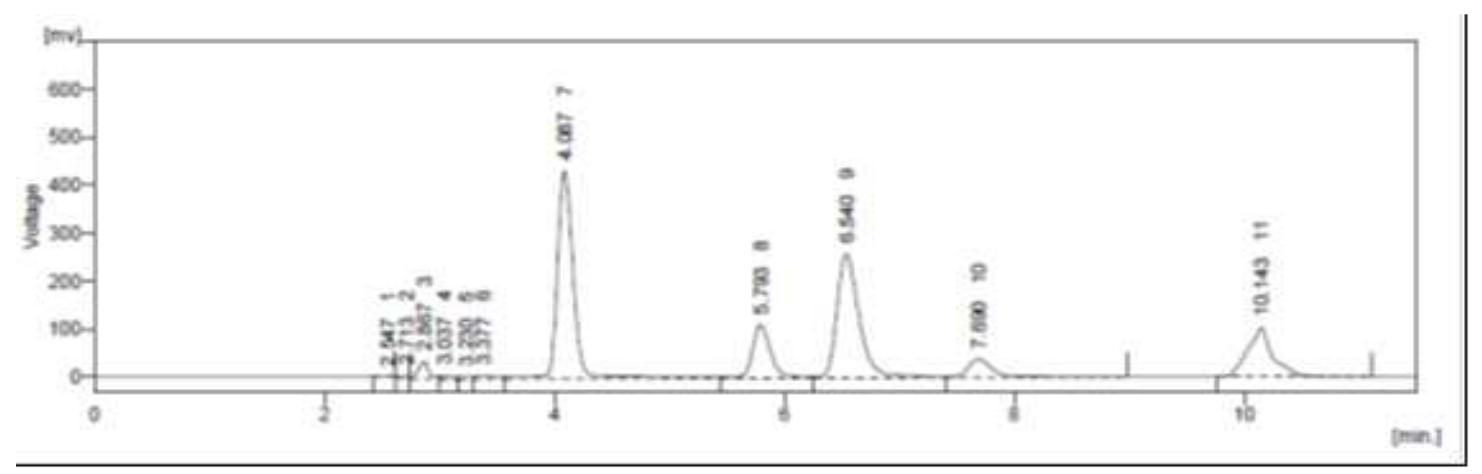


Fig. 7: Sacubitril and valsartan base degradation sample at $4 \mathrm{~h}$

\section{Oxidative degradation}

Oxidative decomposition studies were performed by refluxing $1 \mathrm{ml}$ of sample stock solution was transferred into $10 \mathrm{ml}$ of volumetric flask. $2 \mathrm{ml}$ of $3 \% \mathrm{H}_{2} \mathrm{O}_{2}$ solutions was added and mixed well and put for $4 \mathrm{~h}$ at $70^{\circ} \mathrm{C} 250 \mathrm{ml}$ round bottom flask. After a time period, the content was cooled to room temperature. Then the volume was adjusted with diluent to get $24.5 \mu \mathrm{g} / \mathrm{ml}$ for sacubitril and $25.5 \mu \mathrm{g} / \mathrm{ml}$ for valsartan. After making final solutions, it is injected into HPLC and the peak area and peak shapes were observed. Chromatogram of oxidative degradation on sample solution is shown below in fig. 8 .

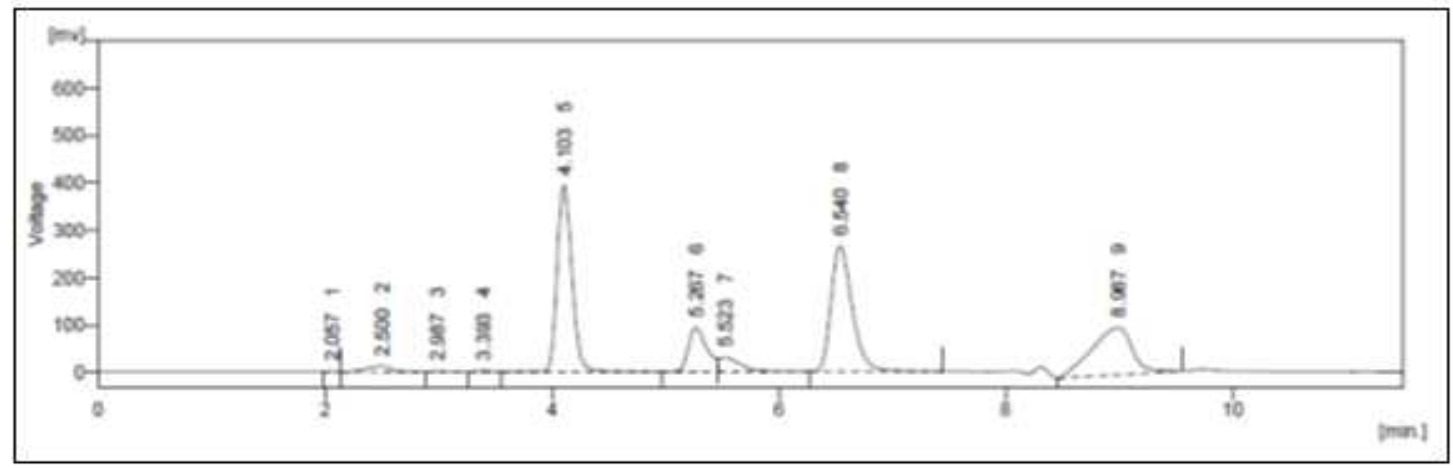

Fig. 8: Sacubitril and valsartan oxidation degradation sample at $4 \mathrm{~h}$

\section{Thermal degradation}

Thermal degradation studies were performed by taking $1 \mathrm{ml}$ of sample stock solution was transferred into $10 \mathrm{ml}$ of volumetric flask. The volumetric flask was stored in an oven at $110{ }^{\circ} \mathrm{C}$ for $4 \mathrm{~h}$. Then the volume was adjusted with diluent to get $24.5 \mu \mathrm{g} / \mathrm{ml}$ for sacubitril and $25.5 \mu \mathrm{g} / \mathrm{ml}$ for valsartan. After making final solutions, it is injected into HPLC and the peak area and peak shapes were observed. Chromatogram of thermal degradation on sample solution is shown below in fig. 9.

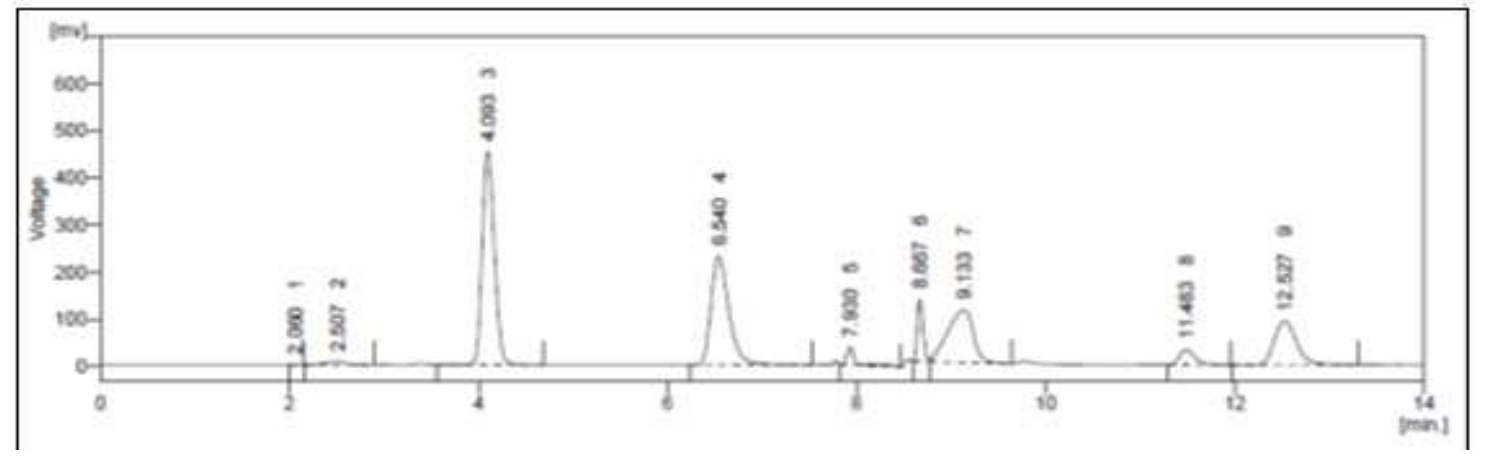

Fig. 9: Sacubitril and valsartan thermal degradation sample at $4 \mathrm{~h}$

\section{Photolytic degradation}

Photo degradation studies were performed by taking $1 \mathrm{ml}$ of sample stock solution was transferred into $10 \mathrm{ml}$ of volumetric flask. The volumetric flask was kept in UV chamber for $72 \mathrm{~h}$. Then the volume was adjusted with diluent to get $24.5 \mu \mathrm{g} / \mathrm{ml}$ for sacubitril and $25.5 \mu \mathrm{g} / \mathrm{ml}$ for valsartan. After making final solutions it is injected into HPLC and the peak area and peak shapes were observed. Chromatogram of photo degradation on sample solution is shown below in fig. 10 .

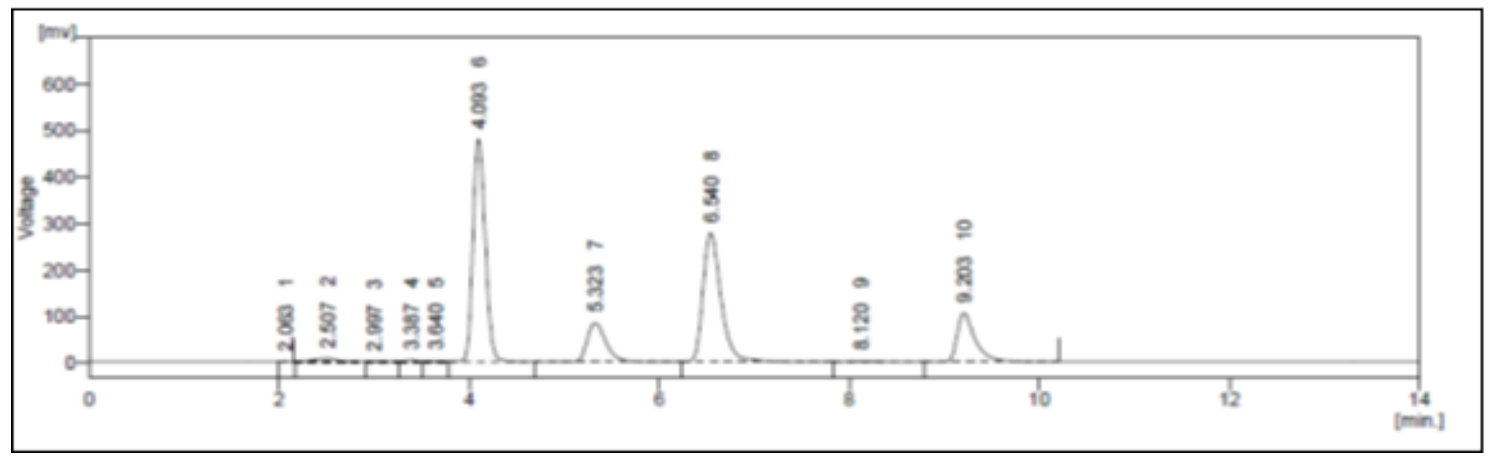

Fig. 10: Sacubitril and valsartan photo degradation sample at $72 \mathrm{~h}$ 
Table 11: Stability data for sacubitril and valsartan

\begin{tabular}{|c|c|c|c|c|}
\hline \multicolumn{5}{|c|}{ Sacubitril standard area for stability-4827.067 } \\
\hline \multirow[t]{2}{*}{ Parameter } & \multicolumn{2}{|c|}{ Standard } & \multicolumn{2}{|l|}{ Sample } \\
\hline & Area & \% degradation & Area & \% degradation \\
\hline Acid & 3613.169 & 25.148 & 3885.979 & 19.496 \\
\hline Base & 3937.527 & 18.428 & 4059.528 & 15.901 \\
\hline Oxidation & 3638.838 & 24.616 & 3645.262 & 24.483 \\
\hline Thermal & 3930.438 & 18.575 & 4050.228 & 16.093 \\
\hline Photo & 4184.313 & 13.316 & 4330.211 & 10.293 \\
\hline \multicolumn{5}{|c|}{ Valsartan standard area for stability-4160.168 } \\
\hline \multirow[t]{2}{*}{ Parameter } & \multicolumn{2}{|c|}{ Standard } & \multicolumn{2}{|l|}{ Sample } \\
\hline & Area & $\%$ degradation & Area & $\%$ degradation \\
\hline Acid & 3607.113 & 13.294 & 3743.630 & 10.013 \\
\hline Base & 3355.132 & 19.351 & 3474.849 & 16.473 \\
\hline Oxidation & 3613.807 & 13.133 & 3459.645 & 16.839 \\
\hline Thermal & 3069.332 & 26.221 & 3026.332 & 27.255 \\
\hline Photo & 3612.071 & 13.175 & 3654.960 & 12.144 \\
\hline
\end{tabular}

Sacubitril and valsartan undergoes significant degradation in acid, base, peroxide, thermal and UV. Comparatively, more degradation was found with acid and peroxide for sacubitril and with thermal for valsartan. Hence, a method of the analysis of sacubitril and valsartan in tablet dosage form shows that the degradation product doesn't interfere with the analytical determination. Hence the proposed analytical method is also useful for the determination of sacubitril and valsartan stability in a sample of the pharmaceutical dosage form.

\section{CONCLUSION}

Stability indicating RP-HPLC methods have been developed and validated for the determination of sacubitril and valsartan in tablet dosage form. The methods are found to be specific as there was no interference of any co-eluting impurities after stress degradation study. The degraded products are well resolved, indicating the method can also be useful for determination of degraded products. The proposed method is found to be simple, accurate, precise and robust. Hence, it can be used successfully for the routine analysis of sacubitril and valsartan in pharmaceutical dosage forms and for analysis of stability samples obtained during accelerated stability study.

\section{ACKNOWLEDGEMENT}

The authors are thankful to Rivan Pharmaceutical Ltd. for providing all the facilities to complete the research work. Special thanks to Yash Pharma and RPG Life Science, Ahmedabad, India, for providing sacubitril and valsartan standards as gift samples.

\section{CONFLICT OF INTERESTS}

Declare none

\section{REFERENCES}

1. National Center for Biotechnology Information. PubChem Compound Database; CID=9811834. Available from: https:// pubchem.ncbi.nlm.nih.gov/compound/9811834. [Last accessed on 10 Mar 2017].

2. Voors AA, Dorhout B, Van Der Meer P. The potential role of valsartan+AHU377 (LCZ696) in the treatment of heart failure. Expert Opin Invest Drugs 2013;22:1041-7.

3. Novartis AG. Novartis' new heart failure medicine LCZ696, now called Entresto, approved by FDA to reduce the risk of cardiovascular death and heat failure hospitalisation. Available fromhttps://www.novartis.com/news/media-releases/Novartisnew-heart-failure-medicine-lcz696-now-called-entrestotmapproved-fda. [Last accessed on 10 Mar 2017].

4. Budavari S. The Merck index. 14th ed. Whitehouse Station. NJ Merck and Co. Press; 2006.

5. Neil MJ, Smith A, Heckelman PE, Kinneary JF. The Merck Index: An Encyclopedia of Chemicals. Edition. 14. Drugs and Biologicals; 2006. p. 1767.

6. Criscione L, Bradley W, Buhlmayer P, Whitebread S, Glazer R, Lloyd $\mathrm{P}$, et al. Clinical advantage of valsartan. Drug Rev 1995;13:230-50.
7. The United States Pharmacopoeia. 31, National Formulary, 26. Vol. 2. US Pharmacopoeia Convention, INC: Rockville M; 2008. p. 3496-8.

8. Kocyigit Kaymacoglu B, Unsalan S, Rollas S. Determination and validation of ketoprofen, pantoprazole, and valsartan together in human plasma by high-performance liquid chromatography. Pharmazie 2006;61:586-9.

9. Daneshtalab N, Lewanczuk RZ, Jamali F. High performance liquid chromatographic analysis of angiotensin-II receptor antagonist valsartan using a liquid extraction method. J Chromatogr B: Anal Technol Biomed Life Sci 2002;766:345-59.

10. Gonzalez L, Lopez JA, Alonso RM, Jimenez RM. Fast screening method for the determination of angiotensin II receptor antagonists in human plasma by high-performance liquid chromatography with fluorimetric detection. J Chromatogr A 2002;8:49-60.

11. Koseki N, Kawashita H, Hara H, Niina M, Tanaka M, Kawai R, et al. Development and validation of a method for quantitative determination of valsartan in human plasma by liquid chromatography-tandem mass spectrometry. J Pharm Biomed Anal 2007;43:1769-74.

12. Li H, Wang Y, Jiang Y, Tang Y, Wang J, Zhao L, et al. A liquid chromatography/tandem mass spectrometry method for the simultaneous quantification of valsartan and hydrochlorothiazide in human plasma. J Chromatogr B: Anal Technol Biomed Life Sci 2007;852:436-42.

13. Macek J, Klima J, Ptacek P. Rapid determination of valsartan in human plasma by protein precipitation and high-performance liquid chromatography. J Chromatogr B: Anal Technol Biomed Life Sci 2006;832:169-72.

14. Satana E, Altinay S, Goger NG, Ozkan SA, Sentürk Z. Simultaneous determination of valsartan and hydrochlorothiazide in tablets by first-derivative ultraviolet spectrophotometry and LC. J Pharm Biomed Anal 2001;5:1009-13.

15. Tatar S, Saglik S. Comparison of UV-and second derivativespectrophotometric and LC methods for the determination of Valsartan in a pharmaceutical formulation. J Pharm Biomed Anal 2002;30:371-5.

16. Chunduri RHB, Dannana GS. Development and validation of a reliable and rapid LC-MS/MS method for simultaneous quantification of sacubitril and valsartan in rat plasma and its application to a pharmacokinetic study. Biomed Chromatogr 2016;30:1467-75.

17. Kena H Patel, Shailesh V, Luhar, Sachin B Narkhede. Simultaneous estimation of sacubitril and valsartan in the synthetic mixture by the RP-HPLC method. J Pharm Sci Biosci Res 2016;6:262-9.

18. ICH guidelines for the stability of new drug substances and products. Q1A(R2) ICH, Geneva; 2005. p. 1-13.

19. ICH guidelines for validation of analytical procedures: text and methodology. Q2(R1) ICH, Geneva; 2005. p. 1-14.

20. Bhatia MS, Kokil SU. Determination and validation of valsartan and its degradation products by isocratic HPLC. J Chem Met 2009;3:1-12. 
21. Parambi DT, Mathew M, Ganesan V. A validated stability indicating HPLC method for the determination of valsartan in tablet dosage forms. J Appl Pharm Sci 2011;1:97-9.

22. Ramachandran S, Mandal BK, Navalgund SG. Stability indicating HPLC method for the simultaneous determination of valsartan and ezetimibe in pharmaceuticals. Top J Pharm Res 2014;13:809-17.

23. Kharoaf M, Malkieh N, Alhasan AM, Shubitah R, Jaradat N, Zaid AN. Tablet formulation and development of $\mathrm{A}$ validated stability indicating HPLC method for quantification of valsartan and hydrochlorothiazide combination. Int J Pharm Pharm Sci 2012;4:683-7.

\section{How to cite this article}

- $\quad$ Shweta Mishra, CJ Patel, MM Patel. Development and validation of stability indicating a chromatographic method for simultaneous estimation of sacubitril and valsartan in pharmaceutical dosage form. Int J Appl Pharm 2017;9(5):1-8. 